Original article

\section{Predominance of Giardia duodenalis All sub-assemblage in young children from Salvador, Bahia, Brazil}

Flávia Thamiris Figueiredo Pacheco ${ }^{1}$, Renata Kelly Novaes Rodrigues Silva ${ }^{1}$, Silvia Souza de Carvalho ${ }^{1}$, Felipe Carvalho Rocha ${ }^{1}$, Gisele Maria Trindade das Chagas ${ }^{1}$, Daisy Chagas Gomes ${ }^{1}$, Hugo da Costa-Ribeiro Junior ${ }^{2}$, Tereza Cristina Medrado Ribeiro², Ângela Peixoto de Mattos², Luciano Kalabric Silva ${ }^{3}$, Neci Matos Soares ${ }^{1}$, Márcia Cristina Aquino Teixeira ${ }^{1}$

${ }^{1}$ Faculdade de Farmácia, Universidade Federal da Bahia, Salvador, Brasil

${ }^{2}$ Centro Pediátrico Professor Hosannah de Oliveira, Universidade Federal da Bahia, Salvador, Brasil ${ }^{3}$ Fundação Oswaldo Cruz, Centro de Pesquisa Gonçalo Moniz, Salvador, Brasil

Introduction. Giardia duodenalis is an intestinal protozoan with a high prevalence in children of developing countries. Molecular studies revealed a great genetic diversity of $G$. duodenalis, with assemblages A and B found mainly in humans. Despite its importance, the information on the molecular epidemiology of human giardiasis is still limited in Brazil. Objective. To characterize G. duodenalis molecular isolates in children from Salvador, Bahia, Brazil.

Materials and methods. Giardia duodenalis positive fecal samples were obtained from 71 children from two day care centers and 39 users of a clinical analysis laboratory. Samples were analyzed by PCR-RFLP of the glutamate dehydrogenase (gdh) and beta-giardin genes and by the sequencing of beta-giardin.

Results. Of the $110 \mathrm{G}$. duodenalis samples, 80 (72.7\%) amplified one or both target genes. Of these, $62(77.5 \%)$ were identified as assemblage A and $18(22.5 \%)$ as assemblage B. The subassemblage All was identified in $58.8 \%(n=47)$ of isolates followed by the sub-assemblage Al (18.8\%, $n=15)$, BIV (11.2\%, $n=9)$, and BIII $(5.0 \%, n=4)$. The All sub-assemblage was the most frequent in children of both day care centers whereas Al was found only in the group attended at the clinical laboratory. Sub-assemblage All predominated in children under two years. Conclusions. The higher frequency of All sub-assemblage suggests that anthroponotic transmission is more common in Salvador, but that zoonotic transmission pathways are also present and a change in susceptibility to different molecular patterns of Giardia may occur during child growth.

Keywords: Giardiasis/epidemiology; child; daycare centers; Brazil.

Predominio del subconjunto All de Giardia duodenalis en niños pequeños de Salvador, Bahía, Brasil

Introducción. Giardia duodenalis es un protozoo intestinal de gran prevalencia en los niños de los países en desarrollo. En estudios moleculares se ha evidenciado la gran diversidad genética de $G$. duodenalis y se han identificado los conjuntos $A$ y $B$, principalmente en humanos. A pesar de su importancia, el conocimiento de la epidemiología molecular de la giardiasis humana aún es limitado en Brasil.

Objetivo. Caracterizar los aislamientos moleculares de G. duodenalis de muestras tomadas a niños de Salvador, Bahía, Brasil.

Materiales y métodos. Las muestras fecales positivas para G. duodenalis se obtuvieron de 71 niños de dos guarderías y de 39 usuarios de un laboratorio de análisis clínicos. Las muestras se analizaron mediante PCR-RFLP de los genes gdh y beta-giardin, y secuenciación de beta-giardin.

Resultados. De las 110 muestras de G. duodenalis, en 80 (72,7\%) se amplificaron uno o ambos genes. De estos, $62(77,5 \%)$ se identificaron como pertenecientes al conjunto A y $18(22,5 \%)$ al B. El subconjunto All se identificó en el $58,8 \%(n=47)$ de los aislamientos, seguido del Al en el 18,8\% ( $n=15)$, el BIV en el $11,2 \%(n=9)$ y el BIII en el $5,0 \%(n=4)$. El subconjunto All fue el más frecuente en los niños de ambas guarderías, en tanto que el Al solo se encontró en el grupo atendido en el laboratorio clínico. El subconjunto All predominó en los niños menores de dos años.

Conclusiones. La mayor frecuencia del subconjunto All sugiere que la transmisión antroponótica es más común en Salvador, pero también existen vías de transmisión zoonóticas, y que pueden ocurrir cambios en la sensibilidad frente a diferentes patrones moleculares de Giardia durante el crecimiento infantil.

Palabras clave: giardiasis/epidemiología; niño; guarderías; Brasil.
Conflicts of interest:

The authors declare that they have no conflicts of interest. 
Giardiasis is of considerable public health importance in developing countries due to its high prevalence in young children and its effects on early childhood diarrhea and malnutrition (1-3). The high susceptibility of children to G. duodenalis infection is usually attributed to the immaturity of their immune system when the first contact with the parasite occurs and poor hygiene habits compared with those of adults (1). The transmission of giardiasis occurs via the fecal-oral route and infection results from the ingestion of cysts present in food or water contaminated with feces $(4,5)$. Direct transmission from person to person also contributes to the dissemination of the parasite among children attending day care centers and schools $(1,6)$.

Although G. duodenalis is considered a unique species, advances in molecular biology techniques have revealed that the protozoan is a complex of species with genetic diversity but morphologically identical, which exhibits adaptation to different hosts $(4,7,8)$. The related Giardia genotypes have been grouped into the eight main assemblages, A, B, C, D, E, F, G, and H, and their respective sub-assemblages $(4,9,10)$. Differences in the gene sequences coding assemblages $A$ and $B$ have made it possible to distinguish genetic groups and subgroups which differ in host specificity (11). Assemblage A was classified into sub-assemblages Al to AIV where Al is usually reported in humans and animals, All is exclusive to man, and Alll and AIV are unique to animals (12). Assemblage B includes sub-assemblages III and IV identified in fecal samples obtained from humans, dogs, cats, horses, calves, and wild animals $(11,13)$.

The geographical distribution of $G$. duodenalis human assemblages varies greatly around the world. In countries such as Bangladesh (14), Portugal (15), Germany (16), Uganda (17), and Syria (18), studies have reported the predominance of assemblage $A$. However, a higher prevalence of human infections by assemblage B was observed in Austria (19, Kenya (20), Libya (21), Canada (22), Egypt (23), and Argentina (24).

In Brazil, there are few studies describing the distribution G. duodenalis genotypes in humans. In Rio de Janeiro, Volotão, et al. (25), identified only assemblage A, mostly classified as All. In São Paulo, the analysis of five isolates of axenic trophozoites had the same results as in Rio, i.e., only assemblage A, mostly All (26). However, in another study conducted in São Paulo with isolates from children in day care centers, assemblage $B$ predominated (27) while in Fortaleza, Kohli, et al. (28), amplified 58 isolates and found assemblage $B$ in $74.1 \%$ of them, $A$ in $15.5 \%$, and mixed infections $(A+B)$ in $10.3 \%$ whereas in the state of Minas Gerais, only type B was found (29). Recently, assemblage $B$ was also reported in patients from the metropolitan area of Rio de Janeiro evidencing changes in the frequency patterns of assemblages A and B over the five-year study (30).

Notwithstanding the high frequency of G. duodenalis infection in Brazil, mainly in young children, the molecular epidemiology of the parasite has been poorly studied, especially in the northeastern region. In the present study, we characterized G. duodenalis isolates from preschool and schoolchildren in Salvador, Bahia, Brazil.

\section{Materials and methods}

\section{Origin of samples}

Giardia-positive stool samples were obtained from children up to 6 years old from two day care centers ( 46 from day care center 1 and 25 from day care center 2) supported by philanthropic institutions and from 39 children under 14 years of 
age attending the clinical analysis laboratory of the Faculty of Pharmacy at the Federal University of Bahia. All children were users of health public services and came from low-income families. Positive samples were identified by centrifugalsedimentation in water (31), centrifugal-fluctuation in zinc sulfate (32), and/or by coproantigen detection using a specific commercial enzyme immunoassay (ELISA; RIDASCREEN Giardia ${ }^{\mathrm{TM}}$, R-Biopharm AG, Germany). To compare the frequencies of specific protozoa assemblages and sub-assemblages, children infected with $G$. duodenalis were divided according to their age and gender.

\section{Molecular characterization of G. duodenalis}

$D N A$ extraction from feces and PCR conditions. DNA from G. duodenalis cysts was purified using QIAamp DNA Stool Mini Kit ${ }^{\mathrm{TM}}$ (Qiagen, Hilden, Germany) following the manufacturer's instructions with some modifications. For example, the time and temperature of the cell lysis step were increased to 10 min at $95^{\circ} \mathrm{C}$ and the DNA elution volume was reduced to $100 \mu \mathrm{l}$ of the buffer.

A 753-bp fragment of the beta-giardin gene was amplified using forward primer G7 and reverse primer G759 (7). In the sequential nested PCR reaction, a 511-bp fragment was amplified using forward primer G99 and reverse primer G609 (33). In all cases, the PCR mixture consisted of 1 X buffer containing $1.5 \mathrm{mM} \mathrm{MgCl}_{2}$, $200 \mu \mathrm{M}$ of each dNTP, $10 \mathrm{pmol}$ of each primer, 2.5 units of Taq DNA polymerase (Invitrogen), and $1 \mu \mathrm{l}$ of purified DNA in a final volume of $25 \mu \mathrm{l}$. The PCR reactions were performed as follows: An initial denaturation step of 5 min at $94^{\circ} \mathrm{C}$ for the first PCR and $15 \mathrm{~min}$ at $95^{\circ} \mathrm{C}$ for the nested-PCR followed by 35 cycles of $30 \mathrm{sec}$ at $94^{\circ} \mathrm{C}, 30 \mathrm{sec}$ of annealing $\left(65^{\circ} \mathrm{C}\right.$ for the primary beta-giardin $\mathrm{PCR}$ and $55^{\circ} \mathrm{C}$ for the nested PCR), and $60 \mathrm{~s}$ at $70^{\circ} \mathrm{C}$ with a final extension of $7 \mathrm{~min}$ at $72^{\circ} \mathrm{C}$.

Additionally, G. duodenalis isolates identified as genotype A through the analysis of the beta-giardin gene were subjected to a semi-nested PCR (snPCR) for amplification of the 384-bp fragment using the direct primers G376 and reverse G759 under the same PCR conditions used for the amplification of the 753-bp beta-giardin fragment (7).

A 432-bp fragment of the gdh gene was amplified using semi-nested PCR as previously described (34). In the primary PCR reaction, the DNA fragment was amplified using forward primer GDHeF and reverse primer GDHiR. In the sequential semi-nested PCR reaction, a 432-bp fragment was amplified using forward primer GDHiF and reverse primer GDHiR. In all cases, the PCR mixture consisted of $1 \mathrm{X}$ buffer containing $2 \mathrm{mM} \mathrm{MgCl}, 200 \mu \mathrm{M}$ of each dNTP (GC:TA = 3:1), $12.5 \mathrm{pmol}$ of each primer, 1 unit of Taq DNA polymerase (Invitrogen), and 1 $\mu \mathrm{l}$ of purified DNA in a final volume of $25 \mu \mathrm{l}$ for the primary PCR and $50 \mu \mathrm{l}$ for the sn-PCR. The PCR reactions were performed as follows: An initial denaturation step of $5 \mathrm{~min}$ at $94^{\circ} \mathrm{C}$ followed by 40 cycles consisting of $30 \mathrm{~s}$ at $94^{\circ} \mathrm{C}, 20 \mathrm{~s}$ of annealing at $65^{\circ} \mathrm{C}$ and $45 \mathrm{~s}$ at $72^{\circ} \mathrm{C}$ with a final extension of $7 \mathrm{~min}$ at $72^{\circ} \mathrm{C}$. All PCR products were analyzed by electrophoresis on ethidium bromide-stained $1 \%$ agarose gels.

Amplicon analyses by RFLP and sequencing. For the characterization of Giardia assemblages, $10 \mu \mathrm{l}$ of the $511 \mathrm{bp}$ beta-giardin amplicon were digested overnight with $10 \mathrm{U}$ of $\mathrm{Haelll}$ in a final reaction volume of $32 \mu \mathrm{l}$ at $37^{\circ} \mathrm{C}(7)$. For identification of A sub-assemblages (AI, All/AllI), the $384 \mathrm{bp}$ fragment produced by SnPCR was digested with the endonuclease $H$ hal as described above (33). The gdh gene was digested overnight at $37^{\circ} \mathrm{C}$ using $10 \mu \mathrm{l}$ of the $432 \mathrm{bp}$ amplicon of the snPCR and $10 \mathrm{U}$ of the enzyme NlaIV (BspLI) in a final volume of $32 \mu \mathrm{l}$. Samples indicating the presence of assemblage B had the amplicons also digested with a second endonuclease, the Rsal, under the same conditions 
to specify sub-assemblages BIII and BIV (34). Restriction fragments were analyzed by $3 \%$ agarose gel electrophoresis using a $50 \mathrm{bp}$ molecular weight standard. The electrophoresis run was performed at 100 volts for two hours.

The isolates with mixed genotype patterns or inconclusive RFLP results were submitted to amplicon sequencing of the beta-giardin gene. PCR products were purified and sequenced by the Macrogen Inc. sequencing service (Macrogen Inc., Seoul, Korea). Nucleotide sequences and electropherograms were analyzed and edited using the program CLC Main Workbench ${ }^{\mathrm{TM}}$, version 8.0 (CLC Bio, Qiagen). To determine the genotype of each sample, the tree phylogenetic analysis was performed using the neighbor-joining method using the MEGA 6 software (35). Beta-giardin gene references corresponding to the different $G$. duodenalis assemblages or sub-assemblages were obtained from GenBank (AY072723, sub-assemblage All; KR051224, sub-assemblage Al; GQ337974, assemblage B; AY072726, sub-assemblage BIII; AY072725, subassemblage BIV; and GQ337973, assemblage E). Sequences were deposited in GenBank under accession numbers MG845536 to MG845549.

\section{Statistical analysis}

The data were analyzed using the IBM SPSS ${ }^{\mathrm{TM}}$ software for Windows and the statistical analyses were performed with the GraphPad Instat ${ }^{\mathrm{TM}}$ program (GraphPad Software, Inc., San Diego, California, USA). The chi-squared test was used to compare the frequency of $G$. duodenalis assemblages and subassemblages according to the age and gender of children while the KruskalWallis followed by Dunn post-test was performed to compare numerical variables. A probability of less than 0.05 was considered significant.

\section{Ethical considerations}

The Ethics Committee of the Nursing School at the Federal University of Bahia, Brazil, approved the study (project approval number 907.867).

Children whose parents agreed to participate in the study and signed an informed consent form were enrolled during the research period. Children over 8 years of age were also informed about the research and signed a consent form. All parasitological test results were sent to the children's parents and individuals with parasitic infections were adequately treated by pediatricians when necessary.

\section{Results}

\section{Genotyping and subgenotyping of G. duodenalis isolates}

From the 110 samples positive for $G$. duodenalis, 80 (72.7\%) had the DNA successfully amplified in one or both genes (Table 1). Fifty-three (48.2\%) isolates were amplified in both loci analyzed, 6 (5.4\%) amplified only betagiardin, and 21 (19.1\%) only gdh (Table 1).

The PCR-RFLP analysis of both target genes and the sequencing of betagiardin revealed assemblage $A$ as the most frequent in the general population as it was found in $77.5 \%(62 / 80)$ of the isolates $(p<0.05)$. Assemblage $B$ was identified in $22.5 \%(18 / 80)$ of the G. duodenalis samples (Table 2 ).

When groups were analyzed separately, assemblage $A$ was significantly more frequent than $B(p<0.05)$ in samples from day care center 1 and laboratory users, whereas in day care center 2 there was no statistical difference in the occurrence of these two genetic types (Table 2). Assemblage B in children was significantly more frequent in day care center $2(11 / 18,61.1 \%, p<0.05)$ than in the other groups. 
Overall, sub-assemblage All was the most frequent (47/80, 58.8\%) followed by $\mathrm{Al}$ $(15 / 80,18.8 \%)$. Of the $18 \mathrm{G}$. duodenalis samples identified as assemblage $\mathrm{B}, 13$ were successfully sub-classified as BIII (5.0\%) and BIV (11.2\%) (Table 2).

Giardia duodenalis sub-assemblage distribution also differed among groups: Al was found only in children's samples from the routine laboratory and 10 of these 15 isolates (66.7\%) were from children under six years of age, i.e., in the same age range as children from the day care centers. A significant predominance of All sub-assemblage $(p<0.05 ; 83.9 \%)$ was observed in day care center 1. On the other hand, although All was the most frequent (54.2\%) type in day care center 2 , no significant difference was found compared to assemblage B frequency (45.8\%). In both day care centers, only All was detected among G. duodenalis isolates identified as assemblage A.

\section{Distribution of sub-assemblages by gender and age}

There was no significant difference in G. duodenalis sub-assemblage the distribution as regards children's gender but there was a difference regarding their age: Al sub-assemblage was more frequently detected in children between 3 and 10 years of age while All was predominant in children under 2 years (Table 3 ). Although few BIV isolates were characterized, they were mostly identified in young children up to 2 years of age.

Table 1. Frequency of beta-giardin and gdh genes amplification

\begin{tabular}{lrr}
\hline Target gene & \multicolumn{1}{c}{$\mathbf{n}$} & \multicolumn{1}{c}{$\mathbf{( \% )}$} \\
\hline beta-giardin & 6 & $(5.4)$ \\
gdh & 21 & $(19.1)$ \\
beta-giardin + gdh & 53 & $(48.2)$ \\
Non-amplified & 30 & $(27.3)$ \\
Total & $110(100.0)$ \\
\hline
\end{tabular}

Table 2. Distribution of Giardia duodenalis assemblages by children groups

\begin{tabular}{lcccc}
\hline \multicolumn{5}{c}{ Frequency of assemblages and sub-assemblages in children groups } \\
$\mathbf{n}(\%)$
\end{tabular}

abcde Equal letters indicate statistically significant differences $(p<0.05$, chi-squared test) in the frequency of assemblages and sub-assemblages among the groups.

Table 3. Distribution of $G$. duodenalis sub-assemblages by gender and age

\begin{tabular}{lccccccc}
\hline \multicolumn{6}{c}{ Frequency of sub-assemblages in children groups } \\
$\mathbf{n}(\%)$
\end{tabular}

${ }^{a b c}$ Equal letters indicate statistically significant differences $(p<0.05$, chi-squared test) in the frequency of sub-assemblages among the groups. ${ }^{*}$ Non-subtyped assemblage B samples 


\section{Discussion}

Advances in molecular biology studies of $G$. duodenalis have shown that the parasite is a multispecies complex with little variation in their morphology but with a great genetic variability. This species is classified into eight distinct assemblages $(A-H)$ but only $A$ and $B$ are regularly found in humans, although they can be detected in other domestic and wild animals $(8,10,36,37)$.

Despite the high prevalence of giardiasis in Brazil, there are few studies on the genetic diversity of $G$. duodenalis. It is rare to find reports from the northeastern region of the country and there are no data of assemblage distribution in the state of Bahia.

In our study, we performed the molecular characterization of 110 isolates of $G$. duodenalis from children living in Salvador who were divided into two groups: children who attended day care centers and those who were seen in a public clinical laboratory. All the isolates were subjected to PCR to amplify beta-giardin and gdh gene fragments. Eighty (72.7\%) samples were successfully amplified in at least one of the genes analyzed with slightly greater success in the amplification rate of $g d h(67.2 \%)$ than in beta-giardin (53.6\%). These genes are often used to detect and/or genotype Giardia isolates from fecal samples but differences in their amplifications have been reported $(27,30)$ suggesting that the presence of divergences between the genomic sequences and primers used for PCR may result in the reduction or even lack of amplification $(37,38)$.

Thirty $(27.3 \%)$ of the isolates in this study did not amplify any of the genes tested. The negative PCR results could be explained by the presence of fecal DNA polymerase inhibitors, such as bilirubin, bile salts, hemoglobin, phenolic compounds, and complex polysaccharides, which are co-purified during the extraction of genomic DNA $(39,40)$. These PCR inhibitors may vary in amount and specific characteristics depending on the diet of each individual.

In this study, we detected assemblages A (77.5\%) and B (22.5\%) with a significant predominance of the former, as found in Spain (41), Germany (16), Portugal (15), Uganda (17), Egypt (42), Syria (18), and Jamaica (43). These results contrast with those from Austria (19), Kenya (20), Libya (21), Canada (22), and Afghanistan (44) where a higher prevalence of assemblage B has been observed. In Latin America, assemblage $B$ has been predominant in Colombia and Argentina, assemblage A in México $(45,46)$ while no difference among these molecular groups was observed in Cuba (47).

In Brazil, due to the huge territorial dimension of the country, the prevalence of $G$. duodenalis assemblages varies between regions. Recent studies in day care children in São Paulo showed a predominance of assemblage B (27) while in pre-school children from a Rio de Janeiro slum, assemblage A was predominant (26). In Fortaleza (28), Minas Gerais (29), and Paraná (48), B molecular isolates were more frequent. However, in studies conducted in Amazonas (49), Rio de Janeiro (30), São Paulo (50), and Santa Catarina (51), assemblages A and B were found in similar proportions. It is important to note that the majority of studies in Brazil performed molecular characterization of less than $50 \mathrm{G}$. duodenalis isolates $(26,29,48,50-53)$. In contrast, in our study, 80 isolates of $G$. duodenalis from different groups of children were analyzed. 
Regarding our sampling, we found differences in G. duodenalis assemblage distribution between groups: In day care center 1 , assemblage A was the most prevalent $(83.9 \% ; p<0,05)$ while no significant differences between $A(54.2 \%)$ and $B(45.8 \%)$ occurrence were observed in day care center 2. The dissemination of $G$. duodenalis cysts through person-toperson contact, common in day care centers, can promote the concentration of certain molecular isolates (27), which may justify the predominance of assemblage $A$ in day care center 1. Additionally, the presence of more than one assemblage in day care center 2 reflects multiple sources of exposure possibly associated with the socioeconomic vulnerability of children seen at this center (54). Considering that the children from the public laboratory group came from locations in Salvador with no relationship among them, the predominance of assemblage A (92\%) suggests a higher frequency of environmental dissemination of this molecular type in the city either through contaminated drinking water and/or food, greens, and other vegetables.

Regarding sub-assemblage characterization, All was the most frequently detected in $58.8 \%$ of cases (47/80) followed by $\mathrm{Al}(18.8 \%)$, BIV $(11.2 \%)$, and BIII (5.0\%). Similarly, studies in other countries have reported a predominance of All sub-assemblage in children $(18,41,55,56)$ and also in some studies conducted in Brazil $(30,51,53)$. However, our results contrast with studies conducted in Rio de Janeiro where most of the isolates were identified as Al (25) while in Paraná (48) and in a day care center in São Paulo (27) BIV predominated. The higher frequency of the All sub-genotype in our study suggests that transmission of giardiasis occurs mainly through an anthroponotic route (direct or indirect) since this subtype is predominantly isolated from humans $(8,10)$.

When we specifically analyzed the distribution of the sub-assemblages in the samples from the two day care centers, there was a higher occurrence of All followed by BIII and BIV. The detection of these subtypes corroborates reports of the role of person-to-person transmission of giardiasis due to agglomeration of individuals in childcare centers since they are predominantly found in humans $(36,57)$, a hypothesis also supported by the absence of the Al sub-assemblage, frequently found in domestic and livestock animals (36). On the other hand, Al sub-assemblage was detected in the majority of children $(60.0 \%, 15 / 25)$ from the public clinical laboratory group. This molecular type is more frequently associated with infection in animals than in humans $(8,46)$ suggesting that poor treatment of drinking water, contamination of water reservoirs with animal excreta, and/or contact with pets (dogs and cats) may be factors involved in the exposure to the parasite in this group.

The occurrence of mixed human infections involving different G. duodenalis molecular isolates has been reported in previous studies with rates varying from 2 to $21 \%$ and higher in developing countries $(7,18,20,33,45,58)$. In our study, isolates with an RFLP pattern suggestive of mixed infections were not confirmed by beta-giardin gene sequencing. The occurrence of mixed infections by various $G$. duodenalis assemblages/sub-assemblages reflects the complex circulation of the parasite in the environment, the exposure of this population to multiple sources of infection, and the lack of cross-immunity between different molecular isolates (20). On the other hand, the occurrence of RFLP profiles suggestive of the concomitant presence of two or more genotypes in the same sample can also be attributed to the heterozygous allelic sequence of the target gene (13), as demonstrated by Morrison, et al. (59), in the G. duodenalis genome project. 
There were no significant differences in G. duodenalis sub-assemblage frequency by gender in this study, which agrees with previous reports $(18,60)$, although another study found $G$. duodenalis molecular type B as the most frequent in females (61). Our results also showed that All sub-assemblage frequency was significantly higher in the 0-2 year age group while the AI was higher in children 3-6 years of age. These results corroborate results from studies reporting a higher prevalence of All genotype in younger children $(18,62)$. The high infection rate of All in younger children can be explained by sub-standard hygiene habits facilitating the transmission of this predominantly anthroponotic sub-assemblage. However, the higher frequency of Al infection in the 3-6 age range may be due to progressive contact with pets possibly facilitating the dissemination of this zoonotic isolate. Nevertheless, we cannot exclude the possibility of intestinal colonization by a new G. duodenalis molecular type due to active immunological memory against a previously eliminated isolate. In fact, studies conducted in Rio de Janeiro at different periods suggest the substitution of one $G$. duodenalis genetic isolate for another in the population $(25,30)$.

In our study, $91.8 \%$ of the children infected with G. duodenalis did not have diarrhea or relevant gastrointestinal symptoms at the time of fecal analysis. Among the giardiasis cases analyzed, out of 9 children (8.2\%) seen at a clinical analysis laboratory seven were symptomatic and had characterized while only two of them had diarrhea (both infected with Al sub-assemblage). The other five had other gastrointestinal symptoms (2 were infected with sub-assemblage All, 2 with Al, and 1 with assemblage B). Given the limited number of symptomatic individuals in our study, it was not possible to evaluate associations between molecular isolates and symptoms. However, it is important to emphasize that asymptomatic children play a role as cyst disseminators in day care centers and in the environment.

Although most G. duodenalis carriers studied were asymptomatic (predominantly of assemblage $A$ ), it is important to highlight the similar distribution of $A$ and $B$ molecular groups in one of the day care centers suggesting that factors intrinsic to the host (age, nutritional status, immunological response, intestinal microbiota) are more relevant in triggering disease than the parasite molecular type involved.

This is one of the few studies of G. duodenalis genetic characterization undertaken in northeastern Brazil and the first one in the state of Bahia. The results show that although All sub-assemblage predominated in the analyzed population suggesting that anthroponotic transmission is more common in our environment, there is a high molecular variability of $G$. duodenalis isolates, which evidences that zoonotic transmission routes can also be present. Apparently, in early childhood, there is a preferential susceptibility to All G. duodenalis sub-assemblage, which changes to Al and possibly BIV in children over three years of age and is maybe related to the development of a subassemblage-specific immune response.

More studies analyzing different groups parasitized by G. duodenalis with a variety of clinical conditions are necessary for a better understanding of the molecular epidemiology of giardiasis.

\section{References}

1. Nesti MM, Goldbaum M. Infectious diseases and daycare and preschool education. J Pediatr (Rio J). 2007;83:299-312. https://doi.org/10.4269/ajtmh.199 0.42.206 
2. Papier K, Williams GM, Luceres-Catubig R, Ahmed F, Olveda RM, McManus DP, et al. Childhood malnutrition and parasitic helminth interactions. Clin Infec Dis. 2014;59:234-43. https://doi.org/10.1093/cid/ciu211

3. Yones DA, Galal LA, Abdallah AM, Zaghlol KS. Effect of enteric parasitic infection on serum trace elements and nutritional status in upper Egyptian children. Trop Parasitol. 2015;5:29-35. https://doi.org/10.4103/2229-5070.145581

4. Thompson RCA. The zoonotic significance and molecular epidemiology of Giardia and giardiasis. Vet Parasitol. 2004;126:15-35. https://doi.org/10.1016/j.vetpar.2004.09.008

5. Ryan U, Hijjawi N, Feng Y, Xiao L. Giardia: An under-reported foodborne parasite. Int J Parasitol. 2019;49:1-11. https://doi.org/ 10.1016/j.ijpara.2018.07.003

6. Thompson RCA. Giardiasis as a re-emerging infectious disease and its zoonotic potential. Int J Parasitol. 2000;30:1259-67. https://doi.org/10.1016/S0020-7519(00)00127-2

7. Cacciò SM, De Giacomo M, Pozio E. Sequence analysis of the beta-giardin gene and development of a polymerase chain reaction-restriction fragment length polymorphism assay to genotype Giardia duodenalis cysts from human faecal samples. Int J Parasitol. 2002;32:1023-30. https://doi.org/10.1016/S0020-7519(02)00068-1

8. Feng Y, Xiao L. Zoonotic potential and molecular epidemiology of Giardia species and giardiasis. Clin Microbiol Rev. 2011;24:110-40. https://doi.org/10.1128/CMR.00033-10

9. Plutzer J, Ongerth J, Karanis P. Giardia taxonomy, phylogeny and epidemiology: Facts and open questions. Int J Hyg Environ Health. 2010;213:321-33. https://doi.org/10.1016/j.ijheh.2010.06.005

10. Thompson RCA, Ash A. Molecular epidemiology of Giardia and Cryptosporidium infections. Infect Genet Evol. 2016;40:315-23. https://doi.org/ 10.1016/j.meegid.2015.09.028

11. Monis PT, Andrews RH, Mayrhofer G, Ey PL. Genetic diversity within the morphological species Giardia intestinalis and its relationship to host origin. Infect Genet Evol. 2003;3:2938. https://doi.org/10.1016/S1567-1348(02)00149-1

12. Ballweber LR, Xiao L, Bowman DD, Kahn G, Cama VA. Giardiasis in dogs and cats: Update on epidemiology and public health significance. Trends Parasitol. 2010;26:180-9. https://doi. org/10.1016/j.pt.2010.02.005

13. Sprong $\mathrm{H}$, Cacciò SM, van der Giessen JWB, ZOOPNET network and partners. Identification of zoonotic genotypes of Giardia duodenalis. PLoS Negl Trop Dis. 2009;3:e558. https://doi.org/10.1371/journal.pntd.0000558

14. Haque R, Roy S, Kabir M, Stroup SE, Mondal D, Houpt ER. Giardia assemblage A infection and diarrhea in Bangladesh. J Infect Dis. 2005;192:2171-3. https://doi.org/10.1086/498169

15. Sousa MC, Morais JB, Machado JE, Poiares-da-Silva J. Genotyping of Giardia lamblia human isolates from Portugal by PCR-RFLP and sequencing. J Eukaryot Microbiol. 2006;53:174-6. https://doi.org/10.1111/j.1550-7408.2006.00221.x

16. Karanis P, Ey PL. Characterization of axenic isolates of Giardia intestinalis established from humans and animals in Germany. Parasitol Res. 1998;84:442-9. https://doi.org/10.1007/s004360050427

17. Johnston AR, Gillespie TR, Rwego IB, McLachlan TLT, Kent AD, Goldberg TL. Molecular epidemiology of cross-species Giardia duodenalis transmission in western Uganda. PLoS Negl Trop Dis. 2010;4:e683. https://doi.org/10.1371/journal.pntd.0000683

18. Skhal D, Aboualchamat G, Al Mariri A, Al Nahhas S. Prevalence of Giardia duodenalis assemblages and sub-assemblages in symptomatic patients from Damascus city and its suburbs. Infect Genet Evol. 2017;47:155-60. https://doi.org/10.1016/..meegid.2016.11.030

19. Lee MF, Auer H, Lindo JF, Walochnik J. Multilocus sequence analysis of Giardia spp. isolated from patients with diarrhea in Austria. Parasitol Res. 2017;116:477-81. https://doi.org/10.1007/s00436-016-5306-9

20. Mbae C, Mulinge E, Guleid F, Wainaina J, Waruru A, Njiru ZK, et al. Molecular characterization of Giardia duodenalis in children in Kenya. BMC Infect Dis. 2016;16:135. https://doi.org/10.1186/s12879-016-1436-z

21. Osman M, El Safadi D, Cian A, Benamrouz S, Nourrisson C, Poirier P, et al. Prevalence and risk factors for intestinal protozoan infections with Cryptosporidium, Giardia, Blastocystis and Dientamoeba among schoolchildren in Tripoli, Lebanon. PLoS Negl Trop Dis. 2016;10:e0004496. https://doi.org/10.1371/journal.pntd.0004496 
22. Iqbal A, Goldfarb DM, Slinger R, Dixon BR. Prevalence and molecular characterization of Cryptosporidium spp. and Giardia duodenalis in diarrhoeic patients in the Qikiqtani Region, Nunavut, Canada. Int J Circumpolar Health. 2015;74:27713. https://doi.org/10.3402/ijch.v74.27713

23. Fahmy HM, El-Serougi AO, El Deeb HK, Hussein HM, Abou-Seri HM, Klotz C, et al. Giardia duodenalis assemblages in Egyptian children with diarrhea. Eur J Clin Microbiol Infect Dis. 2015;34:1573-81. https://doi.org/10.1007/s10096-015-2389-7

24. Minvielle MC, Molina NB, Polverino D, Basualdo JA. First genotyping of Giardia lamblia from human and animal feces in Argentina, South America. Mem Inst Oswaldo Cruz. 2008;103:98-103. https://doi.org/10.1590/s0074-02762008000100015

25. Volotão AC, Costa-Macedo LM, Haddad FSM, Brandão A, Peralta JM, Fernandes O. Genotyping of Giardia duodenalis from human and animal samples from Brazil using betagiardin gene: A phylogenetic analysis. Acta Trop. 2007;102:10-9. https://doi.org/10.1016/j.actatropica.2007.02.010

26. Coradi ST, David EB, Oliveira-Sequeira TC, Ribolla PE, Carvalho TB, Guimarães S. Genotyping of Brazilian Giardia duodenalis human axenic isolates. J Venom Anim Toxins Incl Trop Dis. 2011;17:353-7. https://doi.org/10.1590/S1678-91992011000300016

27. Oliveira-Arbex AP, David EB, Oliveira-Sequeira TCG, Bittencourt GN, Guimarães S. Genotyping of Giardia duodenalis isolates in asymptomatic children attending daycare centre: Evidence of high risk for anthroponotic transmission. Epidemiol Infect. 2016;144:1418-28. https://doi.org/10.1017/S0950268815002514

28. Kohli A, Bushen OY, Pinkerton RC, Houpt E, Newman RD, Sears CL, et al. Giardia duodenalis assemblage, clinical presentation and markers of intestinal inflammation in Brazilian children. Trans R Soc Trop Med Hyg. 2008;102:718-25.

https://doi.org/10.1016/j.trstmh.2008.03.002

29. Santos CK, Grama DF, Limongi JE, Costa FC, Couto TR, Soares RM, et al. Epidemiological, parasitological and molecular aspects of Giardia duodenalis infection in children attending public daycare centers in southeastern Brazil. Trans R Soc Trop Med Hyg. 2012;106:473-9. https://doi.org/10.1016/j.trstmh.2012.05.011

30. Faria CP, Zanini GM, Dias GS, da Silva S, Sousa MC. Molecular characterization of Giardia lamblia: First report of Assemblage B in human isolates from Rio de Janeiro (Brazil). PLOS ONE. 2016;11:e0160762. https://doi.org/10.1371/journal.pone.0160762

31. Pacheco FT, Silva RK, Martins AS, Oliveira RR, Alcântara-Neves NM, Silva MP, et al. Differences in the detection of Cryptosporidium and Isospora (Cystoisospora) oocysts according to the fecal concentration or staining method used in a clinical laboratory. $\mathrm{J}$ Parasitol. 2013;99:1002-8. https://doi.org/10.1645/12-33.1

32. Faust EC, Sawitz W, Tobie J, Odom V, Peres C, Lincicome DR. Comparative efficiency of various technics for the diagnosis of protozoa and helminths in feces. J Parasitol. 1938;25:241-62. https://doi.org/10.2307/3272508

33. Lalle M, Pozio E, Capelli G, Bruschi F, Crotti D, Cacciò SM. Genetic heterogeneity at the beta-giardin locus among human and animal isolates of Giardia duodenalis and identification of potentially zoonotic subgenotypes. Int J Parasitol. 2005;35:207-13. https://doi.org/10.1016/j.ijpara.2004.10.022

34. Read CM, Monis PT, Thompson RC. Discrimination of all genotypes of Giardia duodenalis at the glutamate dehydrogenase locus using PCR-RFLP. Infect Genet Evol. 2004;4:125-30. https://doi.org/10.1016/j.meegid.2004.02.001

35. Tamura K, Stecher G, Peterson D, Filipski A, Kumar S. MEGA6: Molecular Evolutionary Genetics Analysis version 6.0. Mol Biol Evol. 2013;30:2725-9. https://doi.org/10.1093/molbev/mst197

36. Ryan U, Cacciò SM. Zoonotic potential of Giardia. Int J Parasitol. 2013;43:943-56. https://doi.org/10.1016/j.ijpara.2013.06.001

37. Wang H, Zhao G, Chen G, Jian F, Zhang S, Feng C, et al. Multilocus genotyping of Giardia duodenalis in dairy cattle in Henan, China. PLOS ONE. 2014; 9:e100453. https://doi.org/10.1371/journal.pone.0100453

38. Broglia A, Weitzel T, Harms G, Cacció SM, Nöckler K. Molecular typing of Giardia duodenalis isolates from German travellers. Parasitol Res. 2013;112:3449-56. https://doi.org/10.1007/s00436-013-3524-y

39. Wilke H, Robertson LJ. Preservation of Giardia cysts in stool samples for subsequent PCR analysis. J Microbiol Methods. 2009;78:292-6. https://doi.org/10.1016/j.mimet.2009.06.018 
40. Kuk S, Yazar S, Cetinkaya U. Stool sample storage conditions for the preservation of Giardia intestinalis DNA. Mem Inst Oswaldo Cruz. 2012;107:965-8. https://doi.org/10.1590/S0074-02762012000800001

41. Azcona-Gutiérrez JM, de Lucio A, Hernández-de-Mingo M, García-García C, Soria-Blanco $\mathrm{LM}$, Morales L, et al. Molecular diversity and frequency of the diarrheagenic enteric protozoan Giardia duodenalis and Cryptosporidium spp. in a hospital setting in Northern Spain. PLOS ONE. 2017;12:e0178575. https://doi.org/10.1371/journal.pone.0178 575

42. Hussein AH, Rashed SM, El-Hayawan IA, Aly NSM, Abou Ouf EA, Ali AT. Intestinal parasite infections and accuracy of direct thin and thick smear, formol-ether sedimentation, centrifugal flotation, and mini-FLOTAC techniques among patients with gastrointestinal tract disorders from the Greater Cairo Region, Egypt. Am J Trop Med Hyg. 2017;96:589-94. https://doi.org/10.4269/ajtmh.16-0436

43. Lee MF, Cadogan P, Eytle S, Copeland S, Walochnik J, Lindo JF. Molecular epidemiology and multilocus sequence analysis of potentially zoonotic Giardia spp. from humans and dogs in Jamaica. Parasitol Res. 2017;116:409-14. https://doi.org/10.1007/s00436-016-5304-y

44. Kasaei R, Carmena D, Jelowdar A, Beiromvand M. Molecular genotyping of Giardia duodenalis in children from Behbahan, southwestern Iran. Parasitol Res. 2018;117:1425-31. https://doi.org/10.1007/s00436-018-5826-6

45. Ramírez JD, Heredia RD, Hernández C, León CM, Moncada LI, Reyes P, et al. Molecular diagnosis and genotype analysis of Giardia duodenalis in asymptomatic children from a rural area in central Colombia. Infect Genet Evol. 2015;32:208-13. https://doi.org/10.1016/j.meegid.2015.03. 015

46. García-Cervantes PC, Báez-Flores ME, Delgado-Vargas F, Ponce-Macotela, M, Nawa Y, De-la-Cruz-Otero MDC, et al. Giardia duodenalis genotypes among schoolchildren and their families and pets in urban and rural areas of Sinaloa, Mexico. J Infect Dev Ctries. 2017;11:180-7. https://doi.org/10.3855/jidc.8223

47. Torres-Romero JC, Euan-Canto AJ, Benito-González N, Padilla-Montaño N, Huchin-Chan C, Lara-Riegos J, et al. Intestinal parasites and genotyping of Giardia duodenalis in children: First report of genotype B in isolates from human clinical samples in Mexico. Mem Inst Oswaldo Cruz. 2014;109:388-90. https://doi.org/10.1590/0074-0276140507

48. Colli CM, Bezagio RC, Nishi L, Bignotto TS, Ferreira ÉC, Falavigna-Guilherme AL, et al. Identical assemblage of Giardia duodenalis in humans, animals and vegetables in an urban area in southern Brazil indicates a relationship among them. PLOS ONE. 2015;10:e0118065. https://doi.org/10.1371/journal.pone.0118065

49. Coronato Nunes B, Pavan MG, Jaeger LH, Monteiro KJL, Xavier SCC, Monteiro FA, et al. Spatial and molecular epidemiology of Giardia intestinalis deep in the Amazon, Brazil. PLOS ONE. 2016;11:e0158805. https://doi.org/10.1371/journal.pone.0158805

50. David ÉB, Guimarães S, de Oliveira AP, Goulart de Oliveira-Sequeira TC, Nogueira Bittencourt G, Moraes Nardi AR, et al. Molecular characterization of intestinal protozoa in two poor communities in the State of São Paulo, Brazil. Parasit Vectors. 2015;8:103. https://doi.org/10.1186/s13071-015-0714-8

51. Quadros RM, Weiss PHE, Marques, SMT, Miletti LC. Potential cross-contamination of similar Giardia duodenalis assemblage in children and pet dogs in southern Brazil, as determined by PCR-RFLP. Rev Inst Med Trop Sao Paulo. 2016;58:66. https://doi.org/10.1590/S1678-994620165 8066

52. Fantinatti M, Bello AR, Fernandes O, Da-Cruz AM. Identification of Giardia lamblia assemblage $E$ in humans points to a new anthropozoonotic cycle. J Infect Dis. 2016;214:1256-9. http://doi.org/10.1093/infdis/jiw361

53. Seguí R, Muñoz-Antoli C, Klisiowicz DR, Oishi CY, Köster PC, de Lucio A, et al. Prevalence of intestinal parasites, with emphasis on the molecular epidemiology of Giardia duodenalis and Blastocystis sp., in the Paranaguá Bay, Brazil: A community survey. Parasit Vectors. 2018;11:490. https://doi.org/10.1186/s13071-018-3054-7

54. Durigan M, Abreu AG, Zucchi MI, Franco RMB, de Souza AP. Genetic diversity of Giardia duodenalis: Multilocus genotyping reveals zoonotic potential between clinical and environmental sources in a metropolitan region of Brazil. PLOS ONE. 2014;9:e115489. https://doi.org/10.1371/journal.pone.0115489

55. Boontanom P, Pipatsatitpong D, Tan-Ariya P, Mungthin M, Siripattanapipong S, Naaglor T, et al. Incidence and risk factors of Giardia duodenalis infection in an orphanage, Thailand. Trop Biomed. 2014;31:525-33. 
56. Wegayehu T, Karim MR, Li J, Adamu H, Erko B, Zhang L, et al. Multilocus genotyping of Giardia duodenalis isolates from children in Oromia Special Zone, central Ethiopia. BMC Microbiol. 2016;16:89. https://doi.org/10.1186/s12866-016-0706-7

57. Mateo M, Mateo M, Montoya A, Bailo B, Saugar JM, Aguilera M, et al. Detection and molecular characterization of Giardia duodenalis in children attending day care centers in Majadahonda, Madrid, Central Spain. Medicine. 2014;93:e75. https://doi.org/10.1097/MD.00000000000000 75

58. Damitie M, Mekonnen Z, Getahun T, Santiago D, Leyns L. Molecular epidemiology of Giardia duodenalis infection in humans in Southern Ethiopia: A triosephosphate isomerase genetargeted analysis. Infect Dis Poverty. 2018;7:17. https://doi.org/10.1186/s40249-018-0397-4

59. Morrison HG, McArthur AG, Gillin FD, Aley SB, Adam RD, Olsen GJ, et al. Genomic minimalism in the early diverging intestinal parasite Giardia lamblia. Science. 2007;317:19216. https://doi.org/10.1126/science.1143837

60. Nabaa MT, Muhammed OM, Yassir DK. Iraqi genotyping of Giardia lamblia (A,B,E,F) in human stool in AL-Muthanna province -Iraq. Int J Adv Res. 2015;3:757-71.

61. Mohammed Mahdy AK, Surin J, Wan KL, Mohd-Adnan A, Al-Mekhlafi MSH, Lim YAL. Giardia intestinalis genotypes: Risk factors and correlation with clinical symptoms. Acta Trop. 2009;112:67-70. https://doi.org/10.1016/j.actatropica.2009.06.012

62. Tamer GS, Kasap M, Er DK. Genotyping and phylogenetic analysis of Giardia duodenalis isolates from Turkish children. Med Sci Monit. 2015;21:526-32.

https://doi.org/ 10.12659/MSM.892318 